Polonia Sacra 18 (2014) nr 2 (35) · s. 75-99

\author{
ks. Henryk Sławiński ${ }^{1}$ \\ Uniwersytet Papieski Jana Pawła II w Krakowie
}

\title{
Geneza, kontekst i tematyka kazań pasyjnych
}

Głoszenie Chrystusa ukrzyżowanego zajmuje centralne miejsce w przepowiadaniu Kościoła. Bez ogłoszenia tej prawdy nie można powiedzieć, kim jest Chrystus i czym jest droga życia, jaką wskazał dla swoich naśladowców. Bez prawdy o Chrystusie ukrzyżowanym nie można także zrozumieć, czym jest chrześcijaństwo. To prawda, że głoszenie Chrystusa ukrzyżowanego musi być łączone z głoszeniem Chrystusa zmartwychwstałego, bo dopiero oba wydarzenia, jak awers i rewers, stanowią jedną rzeczywistość paschalnego dramatu. Niemniej jednak św. Paweł Apostoł nie wahał się napisać w liście do Koryntian: „my głosimy Chrystusa ukrzyżowanego” (1 Kor 1, 23), widząc w takim stwierdzeniu streszczenie swojego całego posłannictwa przepowiadania słowa Bożego.

Orędzie chwalebnego krzyża z nieodłączną prawdą o zmartwychwstaniu, centralne w nauczaniu Chrystusa i apostołów, zwiastowali ich następcy. Stanowi ono główny temat przepowiadania w ogóle, ale zarówno ze wzglę-

1 Henryk Sławiński - prezbiter diecezji włocławskiej, dr hab., homileta i pedagog, profesor Uniwersytetu Papieskiego Jana Pawła II w Krakowie. Wykładowca homiletyki w Wyższym Seminarium Duchownym w Tarnowie, w Wyższym Seminarium Duchownym Księży Misjonarzy św. Rodziny. Redaktor naczelny czasopisma teologicznego „Polonia Sacra”; sekretarz Stowarzyszenia Homiletów Polskich, członek stowarzyszenia „Arbeitsgemeinschaft für Homiletik”, członek Komisji Języka Religijnego PAN, członek Polskiego Towarzystwa Teologicznego, członek Senackiej Komisji ds. Kontaktów z Zagranicą. Autor kilku książek, wielu artykułów naukowych i publicystycznych, recenzji oraz homilii i kazań. Mieszka w Krakowie. 
du na swoją ważność, jak i tematyczną bliskość względem ludzkich doświadczeń wypełnionych cierpieniami przepowiadanie Chrystusa ukrzyżowanego rozwinęło się w osobnej postaci kazania pasyjnego.

Chociaż kazania pasyjne są stałą praktyką w większości parafii w Polsce i są praktykowane w nieco innym kontekście w innych krajach, nie ma nazbyt obszernej literatury na temat teorii przepowiadania pasyjnego. Istnieje natomiast ogromna liczba tekstów kazań pasyjnych publikowanych zarówno w periodykach z pomocami homiletycznymi, jak i osobnych wydaniach książkowych. Brak hasła na temat kazań pasyjnych we włoskim wydaniu słownika homiletycznego Dizionario di omiletica, którego redaktorami są Manlio Sodi i Achille M. Triacca² ${ }^{2}$ Najobszerniejszym dotychczas opracowaniem na temat posoborowego kaznodziejstwa pasyjnego jest praca doktorska ks. Henryka Sławińskiego z 1996 roku³ $^{3}$ W 2011 roku na Wydziale Teologicznym Uniwersytetu Adama Mickiewicza w Poznaniu Michał Zamelek pod kierunkiem ks. dra Adama Kalbarczyka obronił pracę magisterską zatytułowaną Tematyka współczesnych kazań pasyjnych - na podstawie tekstów publikowanych w periodykach homiletycznych „Biblioteka Kaznodziejska”, ,Materiały Homiletyczne” i „Współczesna Ambona” w latach 1980-2005.

Szczególnie wiele zarówno dla teorii, jak też praktyki przepowiadania pasyjnego uczynił ks. prof. Jan Twardy. Od lat w seminarium duchownym w Przemyślu powstają pod jego kierunkiem serie kazań pasyjnych, opatrzone często cennym wstępem teoretycznym i najczęściej opracowane na kanwie wybranego klucza tematycznego ${ }^{4}$.

\footnotetext{
Torino-Bergamo 1998.

H. Sławiński, Ewangeliczna teologia krzyża w polskim przepowiadaniu pasyjnym po II Soborze Watykańskim, Lublin 1996. Praca ta została opublikowana pt. Przepowiadanie Chrystusowego krzyża, Warszawa 1997; zob. tenże, Jak dzisiaj głosić Chrystusa ukrzyżowanego?, „Ateneum Kapłańskie” 541 (1999), s. 383-396; tenże, Ambiwalentne postawy człowieka wobec cierpienia, „Studia Włocławskie” 10 (2007), s. 213-220; tenże, Naśladowanie Chrystusa ukrzyżowanego według synoptyków, „Studia Włocławskie" 2 (1999), s. 253-265.

Dla przykładu: J. Twardy, Kazania na temat zapowiedzi Męki Pańskiej, [w:] Syn Człowieczy musi wiele cierpieć? Kazania pasyjne, red. J. Twardy, Przemyśl 1997, s. 4-5 (Biblioteka Pomocy Kaznodziejskich, 7); tenże, Kazania pasyjne o siedmiu boleściach Maryi, [w:] Matka Bolesna. Kazania pasyjne, red. J. Twardy, Przemyśl 2003, s. 5-9 (Biblioteka Pomocy Kaznodziejskich, 13); tenże, Głoszenie kazań o świadkach męki Chrystusa, [w:] Świadkowie męki Chrystusa, red. J. Twardy, Przemyśl 2004, s. 5-18.
} 
Ze względu na popularność kazań pasyjnych warto poświęcić im uwagę i podać bardzo syntetyczną genezę kazań pasyjnych, przedstawić różnorodny kontekst ich głoszenia, a także zaproponować struktury kazania pasyjnego oraz tematyki serii kazań pasyjnych, które można opracować.

\section{Geneza kazań pasyjnych}

Kościół głosi Chrystusa ukrzyżowanego, idąc za przykładem swojego Założyciela. Czerpie także ze starożytnej tradycji przepowiadania apostolskiego.

\subsection{Pasyjne nauczanie i dzieło Pana Jezusa oraz opowiadanie ewangelistów o ukrzyżowanym Mesjaszu, Synu Bożym}

Podczas swego publicznego nauczania Pan Jezus wielokrotnie wskazywał, że Jego życie ukierunkowane jest ku wypełnieniu Bożej woli zbawienia ludzi i objawienia bezmiaru Bożej miłości przez cierpienie, haniebną śmierć, zmartwychwstanie i uwielbienie Syna Bożego (por. Mk 8, 31-33; 9, 3032; 10, 32-34; Mt 16, 21-23; 17, 22-23; 20, 17-19; Łk 9, 22.43-45; 18, 31-34). Jezus mówił też, iż warunkiem udziału uczniów w Jego chwale jest zaparcie się samego siebie, wzięcie swego krzyża i naśladowanie Syna Człowieczego (Mk 8, 34; Mt 10, 38; 16, 24; Łk 9, 23; 14, 27; zob. J 12, 25-26). To prawda, że przekaz wypowiedzi Jezusa, jaki posiadamy, został ostatecznie utrwalony po wydarzeniach paschalnych, jednakże sama treść tych wypowiedzi należy do Jezusa, który korygował fałszywe wyobrażenia o obiecanym Mesjaszu. Zresztą pierwsza zapowiedź męki i zmartwychwstania nastąpiła bezpośrednio po wyznaniu Piotra pod Cezareą Filipową. Pozostałe zapowiedzi pozostają pod wpływem tej pierwszej. Spośród ewangelistów jedynie Mateusz, i to tylko przy trzeciej, a zarazem ostatniej zapowiedzi męki i zmartwychwstania Jezusa (Mt 20, 19; por. 26, 2) umieścił wprost słowa o ukrzyżowaniu, gdy mówił o cierpieniach czekających Syna Człowieczego. Pozostałe wypowiedzi ewangelistów synoptycznych na temat wszystkich trzech zapowiedzi męki i zmartwychwstania Jezusa wspominają o pohańbieniu i cierpieniach, ale nigdzie nie zawierają wprost stwierdzenia o ukrzyżowaniu. Joachim Gnilka sugeruje zatem, że wzmianka o ukrzyżowaniu należy do popaschalnego opra- 
cowania Mateusza, a sam Pan Jezus miałby zapowiadać swoją mękę i śmierć, ale bez bezpośredniej wzmianki o ukrzyżowaniu ${ }^{5}$.

Po wydarzeniach paschalnych treść zapowiedzi Jezusa stała się jasna, gdyż została zrealizowana w Jego chwalebnej męce i śmierci na krzyżu. To jednorazowe, historyczne wydarzenie zostało utrwalone w czterech wersjach pozostawionych nam przez ewangelistów. Nie wszyscy, lecz jedynie dwaj spośród czterech ewangelistów zrelacjonowali szczegóły związane z narodzinami Jezusa z Nazaretu w Betlejem. Wszyscy z nich natomiast, komponując swoje relacje ewangeliczne, opisali szczegółowo Jezusową śmierć na krzyżu oraz Jego zmartwychwstanie trzeciego dnia. Toteż można śmiało powiedzieć, że sednem tak pierwotnego kerygmatu, jak i napisanych Ewangelii były opowiadania o męce i krzyżowej śmierci Mesjasza, Jezusa Chrystusa, Syna Bożego. Opowiadania te były rozwinięciem lakonicznego fragmentu wyznania wiary pierwotnego Kościoła: „umęczon pod Ponckim Piłatem, ukrzyżowan,

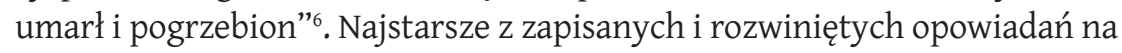
temat centralnego wydarzenia w ludzkich dziejach pochodzi od św. Marka Ewangelisty. Zarówno ta, jak i pozostałe relacje ewangelistów są owocem pierwszych wspomnień zachowywanych starannie ze względu na fascynację Zbawicielem. Owe wspomnienia były zarazem świadectwami o Jezusie. Zanim zostały spisane w znanej nam postaci, zostały poddane selekcji w trakcie pierwotnego przepowiadania i liturgii: jedne fakty i osoby zostały wyakcentowane, inne zaś - przemilczane. Wpływ na ostateczny kształt Ewangelii miały tak cechy ich autorów, jak i wspólnot, do których adresowali orędzie o Chrystusie. Każda z Ewangelii zawiera więc specyficzną myśl teologiczną, o czym należy pamiętać podczas przygotowywania kazań pasyjnych.

\subsection{Ukrzyżowany Chrystus w przepowiadaniu Kościoła}

Orędzie o ukrzyżowaniu Jezusa Chrystusa wraz z relacją o zmartwychwstaniu stanowiło centrum pierwotnego przepowiadania chrześcijańskiego.

\footnotetext{
5 Por. J. Gnilka, Das Matthäusevangelium, Bd. I, Freiburg-Basel-Wien 1986, s. 398; por. H. Sławiński, Przepowiadanie Chrystusowego krzyża, dz. cyt., s. 155.

6 Jan Paweł II, Katechizm Kościoła katolickiego (11.10.1992), Poznań 1994, nr 184; R. Cantalamessa, La vita nella Signoria di Cristo, Milano $1989^{4}$, s. 83; H. Sławiński, Przepowiadanie Chrystusowego krzy$\dot{z} a$, dz. cyt., s. 18-19.
} 
Wspomniane wcześniej ewangeliczne opowiadania o męce i zmartwychwstaniu Jezusa Chrystusa są świadectwem apostolskiego przepowiadania oraz środkiem głoszenia Jezusa ukrzyżowanego i zmartwychwstałego w pierwotnym Kościele. Dla tych, którzy szczerze uwierzyli w Jezusa Chrystusa, relacja z Nim stała się najważniejszą kwestią w życiu, którą chcieli przekazywać innym. Począwszy od pierwotnego przepowiadania aż po nasze czasy Kościół nie przestaje nauczać, że nie ma zbawienia bez wiary w Chrystusa ukrzyżowanego i zmartwychwstałego. Owszem, orędzie krzyża nie jest łatwe do przyjęcia. Przecieżu samego początku, gdy było głoszone przezJezusa (por. Mk 8, 31-33), prowokowało ono zgorszenie. Na opór wobec orędzia krzyża Chrystusowego napotkał w swym przepowiadaniu apostolskim św. Paweł, bo głoszona przez niego mądrość krzyża jawiła się jego słuchaczom jako głupstwo (por. 1 Kor 1, 18) i zgorszenie (por. Ga 5, 11). Jan Paweł II trafnie zauważył, że niełatwe do przyjęcia orędzie krzyża trwa w przepowiadaniu apostołów i Kościoła wszystkich epok. Od nauczania Jezusa, przez nauczanie apostolskie i przepowiadanie ojców Kościoła aż po współczesne kaznodziejstwo pasyjne, prawda o Jezusie ukrzyżowanym zajmowała centralne miejsce w kościelnej posłudze słowa zarówno w liturgii, jaki poza nią: „Kult krzyża Chrystusowego wyznaczył dzieje pobożności chrześcijańskiej i natchnął największych świętych, jakich Kościół wydał na przestrzeni stuleci. Wszyscy, poczynając od św. Pawła, byli «miłośnikami Chrystusowego krzyża» (por. Ga 6, 14)”?.

\section{Kontekst przepowiadania pasyjnego}

Chrystus ukrzyżowany głoszony jest podczas celebracji liturgicznych. Obok nich pobożność ludowa rozwinęła różne nabożeństwa, które stanowią kontekst przepowiadania pasyjnego.

\subsection{Liturgia jako kontekst przepowiadania pasyjnego}

Ukrzyżowanie Jezusa z Nazaretu jako centralne wydarzenie historii zbawienia było zarówno przekazywane w tradycji Kościoła, jak i celebrowane

Por.Jan Paweł II, Przekroczyć próg nadziei.Jan Paweł II odpowiada na pytania Vittoria Messoriego, Lublin 1994, s. 72. 
w liturgii. Odnalezione w 1884 roku dzieło Itinerarium Egeriae (albo Aetheriae) zawiera opisy pewnej pątniczki, Egerii bądź Eterii, z jej podróży do Egiptu, Palestyny i Syrii, zrealizowanej pod koniec IV wieku. Ta wnikliwa obserwatorka życia religijnego opisała w swym dzienniku z podróży między innymi nabożeństwa chrześcijańskie, w których brała udział. Znalazło się wśród tych opisów również najstarsze znane nam świadectwo o nabożeństwie pasyjnym - relacja z nabożeństwa odprawianego w Wielki Piątek w Jerozolimie. Według relacji pątniczki rozpoczęło się w ono w południe i trwało przez trzy godziny, stosownie do czasu konania Pana Jezusa na krzyżu. Nabożeństwo wypełnione było czytaniami o męce Chrystusa, które były przerywane przez modlitwy i hymny. Czytano zarówno teksty Starego Testamentu odnoszące się do męki Chrystusa, jak i ewangeliczne opisy męki Pańskiej. Częścią nabożeństwa było wystawienie i uczczenie drzewa krzyża świętego, którego biskup i diakoni pilnie strzegli, ponieważ pamiętano fakt, że ,jakiś człowiek odgryzł kawałek relikwii i uciekł!"’.

Istnieją starożytne świadectwa dotyczące liturgicznej proklamacji męki Pańskiej. Według Liber comitis z V wieku w liturgii rzymskiej odczytywano opowiadania o męce Pańskiej w relacji poszczególnych ewangelistów: w Niedzielę Palmową - według św. Mateusza, w Wielką Środę - według św. Łukasza, a w Wielki Piątek - według św. Jana ${ }^{10}$. W czasach papieża Leona I Wielkiego odczytywano mękę Pańską także w liturgii Wigilii Paschalnej ${ }^{11}$. Echo lektury biblijnej powracało w kazaniach, w których podejmowano motywy pasyjne, czego przykładem są nawiązania do Męki Chrystusa w kazaniach św. Augustyna ${ }^{12}$.

8 Itinerarium Aetheriae; Sources Chrétiennes 21; Corpus Christianorum. Series Latina 175, 37-103; Peregrinatio Aetheriae, [w:] G. E. Gingras New Catholic encyclopedia 2003, www.encyclopedia. com/article-1G2-3407703567/egeria-itinerarium.html; por. Leksykon liturgii, oprac. B. Nadolski, Poznań 2006, s. 1622-1623.

9 R. Harries, Wstęp, [w:] Siedem ostatnich słów z krzyża. Odczytywane dzisiaj, red. E. Nevell, przekł. A. Nowak, Kraków 2004, s. 11.

10 Liber comitis; Patrologia Latina [dalej: PL], 30, 502-503.

11 Leon Wielki, Sermo 52, 5; PL 54316.

12 Św. Augustyn nawiązywał do czytania męki Pańskiej według św. Mateusza (Sermones de tempore 232; PL 38, 1108); W. Pałęcki, Pasja. W liturgii, [w:] Encyklopedia katolicka, t. 14, red. E. Gigilewicz, Lublin 2010, k. 1432. 
Najstarsze relacje z liturgii Wielkiego Piątku odprawianej w Rzymie pochodzą dopiero z VII wieku. Opisana została liturgia papieska z tego okresu sprawowana w kościele św. Krzyża Jerozolimskiego, która obejmowała proklamację męki Pańskiej według św. Jana oraz bardzo rozwiniętą modlitwę powszechną, a także procesję z relikwiami krzyża i Komunię Świętą dla wiernych. W średniowieczu ukształtował się przebieg liturgii wielkopiątkowej znany do dziś, a więc złożonej z proklamacji męki Pańskiej według św. Jana, długiej modlitwy powszechnej, uczczenia krzyża oraz przyjęcia Komunii Świętej ${ }^{13}$.

Tajemnica męki i krzyżowej śmierci oraz zmartwychwstania i wniebowstąpienia Chrystusa stanowi centrum przepowiadania chrześcijańskiego w ciągu roku liturgicznego. Według Jana Pawła II „Kościół wschodni skoncentrował się w swojej liturgii przede wszystkim na zmartwychwstaniu. Kościół zachodni, zachowując prymat zmartwychwstania, poszedł bardziej w kierunku pasyjnym" ${ }^{14}$. Same opowiadania o męce Pańskiej - najdłuższe pośród perykop proklamowanych w liturgii niedzielnej - udostępniane są słuchaczom w relacji ewangelistów synoptycznych w Niedziele Palmowe roku „A”, „B” i „C”, a w relacji św. Jana co roku w Wielki Piątek. Obszerność tych perykop nie zwalnia z obowiązku wygłoszenia w tym dniu krótkiej homilii. Nie jest ona najodpowiedniejsza do dłuższej refleksji nad problematyką ludzkiego cierpienia. Stąd też zrodziło się wśród wiernych zapotrzebowanie na dłuższe medytacje o tematyce pasyjnej. Odpowiedzią na to zapotrzebowanie był rozwój nabożeństw, których integralną częścią stało się długie kazanie pasyjne. Wśród nich najbardziej znane są nabożeństwo siedmiu ostatnich słów Chrystusa, praktykowane w środowisku katolickim, ale także wśród protestantów, oraz typowo polskie i katolickie nabożeństwo gorzkich żali.

\subsection{Pobożność pasyjna kontekstem kazania pasyjnego}

Obok liturgii Wielkiego Piątku rozwinęły się z czasem różne nabożeństwa służące rozważaniu męki Pańskiej, czyli nabożeństwa pasyjne, należące do najstarszych przejawów pobożności ludowej. Rozwinęła się ona szczególnie

13 Por. Leksykon liturgii, oprac. B. Nadolski, Poznań 2006, s. 1623.

14 Przekroczyć próg nadziei. Jan Paweł II odpowiada na pytania Vittoria Messoriego, dz. cyt., s. 72. 
począwszy od XI wieku ${ }^{15}$.Z biegiem czasu rozwinął się cały nurt duchowości chrześcijańskiej, odznaczający się tendencją do przeżywania męki Pańskiej po to, by osiągnąć doskonałość moralną. Nurt ten, nazwany duchowością pasyjną, rozwijał się w Kościele szczególnie wraz z kultem człowieczeństwa Jezusa Chrystusa, a swoje natężenie osiągnął w okresie średniowiecza we franciszkańskiej szkole duchowości. Jej wybitnym przedstawicielem był św. Bonawentura. Według niego rozważanie męki Pańskiej stanowiło podstawę osiągnięcia doskonałości chrześcijańskiej. W nurcie tym św. Franciszek z Meyronnes († 1328) wyzywał do wdzięczności Zbawicielowi za jego mękę, a św. Aniela z Foligno († 1309) i św. Katarzyna z Bolonii († 1463) przedstawiały umęczonego Chrystusa jako niedościgniony wzór miłości do bliźniego, a także pokory i posłuszeństwa ${ }^{16}$. Wszyscy oni zachęcali do kontemplowania męki i śmierci krzyżowej Chrystusa, podobnie jak Hubert z Casale († 1329), św. Jan Kapistran († 1456) i Jakub z Todi († 1306). Obok wspomnianych wyżej wybitnych przedstawicieli duchowości pasyjnej należy jeszcze wymienić św. Ignacego Loyolę, który także pielęgnował duchowość pasyjną, dając jej wyraz w swoich ćwiczeniach duchowych. W Polsce zaś znanym przedstawicielem szkoły duchowości pasyjnej był Kasper Drużbicki, który nawiązywał do myśli błogosławionego Henryka Suzo ${ }^{17}$.

Dużą wagę do rozważania męki Pańskiej na drodze do osiągnięcia doskonałości chrześcijańskiej przywiązywał św. Paweł od Krzyża († 1775), który nawet założył Zgromadzenie Męki Jezusa Chrystusa, czyli tak zwanych pasjonistów. Jego członkom polecił składanie, obok ślubów posłuszeństwa, czystości i ubóstwa, także dodatkowego ślubu szerzenia nabożeństwa męki Pańskiej ${ }^{18}$.

Tradycyjne i do dziś praktykowane formy pobożności pasyjnej w postaci rozważania męki Pańskiej utrwaliły swój kształt i upowszechniły się na przełomie XVI i XVII wieku. W XVI wieku rozwinęło się - z inspiracji franciszkanów w Hiszpanii - nabożeństwo drogi krzyżowej (łac. via dolorosa). Jego wielkim propagatorem i popularyzatorem w Italii był franciszkanin

15 Por. tamże.

16 Por. J. M. Popławski, Duchowość pasyjna, [w:] Leksykon duchowości katolickiej, red. M. Chmielewski, Lublin-Kraków 2002, s. 637.

17 Por. tamże; J. M. Popławski, Kaspra Drużbickiego teologia krzyża, Lublin 1997.

18 J. M. Popławski, Duchowość pasyjna, dz. cyt., s. 637-638. 
św. Leonard z Porto Maurizio (1678-1751), który nadał mu dzisiejszy kształt. W ciągu swojego życia przyczynił się on do erygowania co najmniej 572 dróg krzyżowych i wpłynął na jej erygowanie przez papieża Benedykta XIV w rzymskim Koloseum ${ }^{19}$. Z czasem praktyka nabożeństwa drogi krzyżowej stała się najbardziej popularnym na świecie wyrazem duchowości pasyjnej.

\subsection{Nabożeństwo siedmiu słów}

W tym też okresie, pod koniec XVII wieku, rozwinęło się kaznodziejstwo pasyjne polegające na rozważaniu ostatnich siedmiu słów Jezusa w kontekście nabożeństwa kościelnego. Źródłem dla owych kazań były zapisane w Ewangeliach słowa, które Pan Jezus wypowiedział, wisząc na krzyżu:

1. „Ojcze, przebacz im, bo nie wiedzą, co czynią” (Łk 23, 34);

2. „Zaprawdę, powiadam ci: Dziś ze Mną będziesz w raju” (Łk 23, 43);

3. „Niewiasto, oto syn Twój. [...] Oto Matka twoja” (J 19, 26-27);

4. „Eli, Eli, lema sabachthani? [...] Boże mój, Boże mój, czemuś Mnie opuścił?" (Mt 27, 46);

5. „Pragnę” (J 19, 28);

6. „Wykonało się!” (J 19, 30);

7. „Ojcze, w Twoje ręce powierzam ducha mojego” (Łk 23, 46) ${ }^{20}$.

Inspiracją dla nabożeństwa siedmiu ostatnich słów Chrystusa była modlitwa z VIII wieku autorstwa Bedy Czcigodnego. Jej treścią było rozważanie męki Jezusa na kanwie Jego słów wypowiedzianych podczas konania na krzyżu. Owych siedem słów Jezusa przeciwstawiano siedmiu grzechom głównym ${ }^{21}$.

Do upowszechnienia tego nabożeństwa przyczynił się peruwiański jezuita Alonso Messia Bedoyi ${ }^{22}$. Zainicjował je w stolicy kraju, Limie, naj-

19 Por. Z. Pałubska, Leonard z Porto Maurizio, [w:] Encyklopedia katolicka, t. 10, red. A. Bednarek, Lublin 2004, k. 789-790; J. M. Popławski, Droga krzyżowa, [w:] Leksykon duchowości katolickiej, dz. cyt., s. 222-223; Leksykon liturgii, dz. cyt., s. 1665. Do popularyzacji nabożeństwa przyczyniła się łaska odpustu przyznana za uczestnictwo w nim - por. Corrado Maggioni, Via Pacis - Via Crucis - Via Matris - Via Lucis, [w:] Dizionario di omiletica, red. M. Sodi, A. M. Triacca, Torino-Bergamo 1998, s. 1652.

20 Por. R. Harries, Wstęp, dz. cyt., s. 11-12.

21 Por. tamże, s. 12.

22 Zob. A. Messia, The devotion of the three hours' agony on good friday, London 1899. 
prawdopodobniej w związku z trzęsieniem ziemi, jakie nawiedziło Peru w 1687 roku. Wiele osób odczytywało katastrofę naturalną jako karę Bożą za grzechy ${ }^{23}$.

Rozważanie męki Pana Jezusa w formie nabożeństwa poświęconego siedmiu słowom z krzyża w wersji Messiego zyskało znaczną popularność w Ameryce Łacińskiej, a następnie zdobyło uznanie także w Europie ${ }^{24}$. Nie bez znaczenia dla spopularyzowania nabożeństwa siedmiu słów Jezusa z krzyża było trzęsienie ziemi, które 1 listopada 1755 roku nawiedziło Portugalię i Hiszpanię. Oprócz Lizbony, która ucierpiała najbardziej, zniszczenia spowodowane trzęsieniem ziemi dotknęły także inne miasta, między innymi hiszpański port Kadyks. Został on zalany falą tsunami o wysokości 18 metrów ${ }^{25}$. Wierni próbowali bezradnie wytłumaczyć okoliczności tej tragedii w świetle wiary i odkryć sens tego „dopustu Bożego”. Grupa pobożnych katolików z Kadyksu zrzeszona w Bractwie Przedwiecznej Matki (la Cofradía de la Madre Antigua) z inspiracji swego duchowego opiekuna ks. Don José Sáenza de Santamaríi zaczęła w tym czasie odprawiać nabożeństwo siedmiu słów Jezusa z krzyża. Ów zamożny duchowny ufundował nawet wspaniałe oratorium nad grotą Santa Cueva, które poświęcono w 1783 roku $^{26}$. Nabożeństwo siedmiu słów Jezusa z krzyża przyjęło się w Kadyksie i około 1786 roku kanonicy z tego miasta zwrócili się do Józefa Haydna z prośbą, by skomponował muzykę do odprawianego w katedrze nabożeństwa pasyjnego na kanwie siedmiu słów Chrystusa wypowiedzianych na krzyżu.

W 1801 roku Józef Haydn (1732-1809) zanotował:

Mniej więcej piętnaście lat temu kanonicy z Kadyksu zwrócili się do mnie z prośbą o skomponowanie utworu instrumentalnego opartego na siedmiu słowach Chrystusa wypowiedzianych na krzyżu. W owym czasie istniał zwyczaj, że każdego roku w okresie Wielkiego Postu w katedrze w Kadyksie wykonywano jakieś oratorium [...]. Ściany, okna i kolumny w kościele były przybrane czarnym materiałem, zaś nastrój religijnej powagi i smutku podkreślała tylko jedna duża lampa, zawieszona w środkowej części świątyni. W południe zamykano wszystkie drzwi i zaczynała grać muzyka. Po sto-

\footnotetext{
23 Por. R. Harries, Wstęp, dz. cyt., s. 14.

24 Por. tamże, s. 12.

25 Por. tamże, s. 14.

26 Por. tamże, s. 12.
} 
sownym na tę okoliczność preludium na ambonę wchodził biskup, odczytywał jedno z siedmiu słów i przedstawiał medytację na jego temat. Następnie schodził z ambony i klękał przed ołtarzem. Interludium wypełniała muzyka. Potem znowu biskup wchodził na ambonę, wygłaszał medytację i schodził z ambony, i za każdym razem, po zakończeniu medytacji, orkiestra podejmowała grę ${ }^{27}$.

Oratorium Józefa Haydna na temat siedmiu ostatnich słów Chrystusa na krzyżu, złożone z siedmiu sonat poprzedzonych introdukcją, było zwieńczone fragmentem Il Terremoto (trzęsienie ziemi) - nawiązującym do trzęsienia ziemi przy śmierci Chrystusa (por. Mt 27, 51) i do Jego zmartwychwstania. Oratorium to zostało wykonane w ramach nabożeństwa pasyjnego po raz pierwszy w Kadyksie w Wielki Piątek 1787 roku. Szybko zyskało popularność i doczekało się wersji na kwartet i kwintet smyczkowy, fortepianowej oraz wokalnej ${ }^{28}$. Połączenie nabożeństwa siedmiu ostatnich słów Chrystusa na krzyżu ze wspaniałą muzyką oratoryjną sprawiło, że owo trzygodzinne nabożeństwo pasyjne stało się bardzo popularne w Europie. Dla kaznodziejów stanowiło ono znakomity bodziec do opracowywania własnych rozważań męki Pańskiej ${ }^{29}$.

Protestanci, którzy głoszą krzyż jako środek odkupienia ludzkości przez Chrystusa, zaadaptowali powstałe na gruncie katolickim trzygodzinne nabożeństwo na kanwie siedmiu słów Chrystusa wypowiedzianych z krzyża i włączyli do swoich obchodów Wielkiego Piątku. Anglikanie odprawiają to nabożeństwo od 1864 roku $^{30}$, a w katedrze św. Pawła w Londynie od 1878 roku. Była to ich pierwsza katedra, w której od tamtej pory zaczęto na stałe odprawiać to nabożeństwo pasyjne ${ }^{31}$.

27 H. Thurston, Lent and Holy Week, London 1906, s. 383-384; cyt. za: R. Harries, Wstęp, dz. cyt., s. 13.

28 R. Harries, Wstęp, dz. cyt., s. 13.

29 ,...] sukces muzyki Haydna zaowocował zmianą oryginalnego formatu opracowanego przez Messiego. Pierwotnie bowiem było tak, że po każdej medytacji następowała chwila ciszy, a potem odczytywano odpowiednie wersety z Pisma Świętego i odmawiano modlitwy. Wedle nowego formatu, wzorowanego na kompozycji Haydna, po każdej medytacji rozbrzmiewała muzyka" - tamże, s. 14-15.

30 Por. tamże, s. 15.

${ }_{31}$ Por. tamże, s. 16. 


\subsection{Gorzkie żale kontekstem kazań pasyjnych w Polsce}

Wśród najbardziej znanych nabożeństw pasyjnych w Polsce obok drogi krzyżowej wymienić trzeba popularne nabożeństwo gorzkich żali ${ }^{32}$. Służy ono wiernym do rozważania męki Pańskiej i stanowi ważny kontekst dla kazania pasyjnego.

Na kształt gorzkich żali wpłynęły pobożność pasyjna XVII i początku XVIII wieku, polskie pieśni, misteria i dialogi pasyjne oraz ówczesna jutrznia brewiarzowa, na którą składało się Invitatorium (wezwania) i trzy nokturny. Odpowiednio do modlitwy liturgicznej zorganizowane zostało nabożeństwo Ludu Bożego, jakim są gorzkie żale. Rozpoczynają się one Pobudką, czyli wezwaniem do medytacji nad męką Pańską. Rolę trzech nokturnów złożonych z psalmów i hymnów biblijnych pełnią trzy części gorzkich żali wypełnione pieśniami pasyjnymi zatytułowanymi każdorazowo: Hymn, Lament duszy nad cierpiacym Jezusem i Rozmowa duszy z Matką Bożą Bolesna. Przed tymi pieśniami, a więc na początku każdej części, podawane są intencje modlitwy ${ }^{33}$.

Nabożeństwo gorzkich żali zostało opracowane przez ks. Wawrzyńca Stanisława Benika (†1720) ze zgromadzenia księży misjonarzy św. Wincentego à Paulo. Ks. Benik przygotował tekst i melodię nabożeństwa, gdy pracował przy kościele Świętego Krzyża w Warszawie. Uczynił to na życzenie swego przełożonego, proboszcza parafii, a zarazem wizytatora polskiej prowincji księży misjonarzy, ks. Michała Bartłomieja Tarły CM, notabene późniejszego biskupa poznańskiego († 1715). Nabożeństwo pasyjne w kształcie zaproponowanym przez księdza Benika zostało przyjęte przez wiernych z entuzjazmem. W formie drukowanej gorzkie żale zostały wydane w 1707 roku pod długim, barokowym tytułem Snopek Mirry z Ogrodu Gethsemańskiego albo żałosne gorzkiej męki Syna Bożego rozpamiętywanie... ${ }^{34}$.

32 Zob. M. Chorzępa, Gorzkie żale, ich geneza i rozwój historyczny, „Nasza Przeszłość” 12 (1969), s. 221-258; W. Szymoniak, Gorzkie Żale, „Materiały Homiletyczne” 40 (1981), s. 4-7; M. Bańbuła, B. Bartkowski, Gorzkie Żale, [w:] Encyklopedia katolicka, t. 5, red. L. Bieńkowski, Lublin 1989, k. 1309-1311.

33 Por. T. Sinka, Gorzkie Żale: geneza, teologia, przyszłość, „Ruch Biblijny i Liturgiczny” 54 (2001) nr 1, s. 51.

34 Por. tamże, s. 51-52. 
Od tamtej pory nabożeństwo gorzkich żali było odprawiane w kościele Świętego Krzyża we wszystkie niedziele Wielkiego Postu. Z czasem zaś zostało spopularyzowane w innych kościołach misjonarzy św. Wincentego à Paulo. Duże znaczenie dla popularyzacji nabożeństwa miał fakt, że w owym czasie księża misjonarze nauczali w ponad dwudziestu seminariach duchownych. Uformowani przez nich księża wprowadzali w parafiach nabożeństwo, które poznali w seminarium. Również emigranci z Polski pielęgnowali tradycję śpiewania gorzkich żali poza ojczyzną, w ośrodkach polonijnych ${ }^{35}$.

Nabożeństwo gorzkich żali ma ponadtrzystuletnią tradycję. Pozostało niezmienione, opierając się różnym działaniom reformatorów, pragnących je zmienić czy ulepszyćc ${ }^{36}$. Melodie pieśni pasyjnych stosowane podczas nabożeństwa wytwarzają szczególny klimat sprzyjający rozważaniu i przeżywaniu męki Pańskiej37. Pomagają uczestnikom we wzbudzeniu skruchy i żalu za grzechy.

Jak zauważa ksiądz profesor Edward Staniek, w kazaniach pasyjnych trzeba uwzględnić atmosferę tworzoną przez nabożeństwo gorzkich żali. W nich „Ewangelia jest opowiadana z trzech punktów widzenia: człowieka, który rozważa mękę; Jezusa, który ją przeżywa, i Jego bolesnej Matki. Nigdy kaznodzieja nie ma tak dobrze przygotowanego terenu do przekazywania pasyjnych treści, jak w czasie Gorzkich żali”38.

\section{Tematyka kazań pasyjnych}

Istotnym elementem gorzkich żali jest kazanie pasyjne. Służy ono refleksji nad męką Chrystusa oraz jej znaczeniem dla współczesnych chrześcijan. Celem kazań pasyjnych jest pomoc wierzącym w przeżyciu misterium Jezusa w powiązaniu z ich własnym życiem. Chodzi w nich także o ukazanie, że orędzie zawarte w ewangelicznych opowiadaniach o męce Pańskiej odnosi się do problemów współczesnego świata. Zdaniem Tarsycjusza Sinki „głównym

\footnotetext{
Por. tamże, s. 52.

Por. tamże, s. 54.

Por. tamże, s. 53.

38 E. Staniek, Z kaznodziejskiego warsztatu, Kraków 1997, s. 106-107.
} 
celem rozważania męki Pańskiej jest wielbienie majestatu Ojca niebieskiego i dziękczynienie za Jego wielką miłość ku rodzajowi ludzkiemu, że raczył zesłać swojego Syna po to, by podjął mękę i śmierć na krzyżu dla naszego zbawienia. Rozważanie męki Pańskiej z wszystkimi okrucieństwami pomaga lepiej i głębiej pojąć grzech, jego złość, a także wielkość łaski przebaczenia płynącej z misterium męki Zbawiciela [...]. Człowiek dowiaduje się, że cierpienia mają moc zbawczą. Cierpienia człowieka w łączności z cierpieniami Chrystusa nabierają mocy zbawczej dla siebie i dla drugich. Rozważanie męki Pańskiej odgrywa zatem ważną rolę w życiu religijnym człowieka"39. Kazanie pasyjne służy też przypomnieniu obietnicy wypowiedzianej przez św. Pawła w Liście do Tymoteusza, że jeżeli z Chrystusem współcierpimy, to również z Nim królować będziemy (2 Tm 2, 12).

\subsection{Chrystus ukrzyżowany głównym tematem kazań pasyjnych}

Podstawowym tematem kazań pasyjnych jest Chrystus ukrzyżowany. Źródłem zaś do tych kazań są opowiadania czterech ewangelistów. Cennym ich uzupełnieniem, które również stanowi źródło dla kazań pasyjnych, jest Pawłowa teologia krzyża. Jako że paschalny dramat Chrystusa ukrzyżowanego został zapowiedziany i przygotowany w Starym Testamencie, należy czerpać treść do kazań pasyjnych także z Biblii hebrajskiej. Innym źródłem są Dzieje Apostolskie oraz pozostałe księgi Nowego Testamentu, w których zawarte jest orędzie o ofierze Chrystusa i jej historiozbawczym znaczeniu ${ }^{40}$. Pomocą w opracowaniu kazań pasyjnych służą nauczanie Kościoła oraz teologia dogmatyczna - a w niej zwłaszcza chrystologia i soteriologia - uwydatniająca przewodnie tematy historii zbawienia ${ }^{41}$.

Mówiąc o Chrystusie ukrzyżowanym, należy omówić jednorazowość, jedyność i nieporównywalności męki Chrystusa, a zarazem dostępność jej owoców dla wszystkich ludzi w każdej epoce. Cierpienie Chrystusa było zbawienną ofiarą podjętą za zbawienie ludzi. Ofiara ta została podjęta przez Niego

39 Por. T. Sinka, Gorzkie Żale: geneza, teologia, przyszłość, dz. cyt., s. 53.

40 Por. J. Twardy, Treść kazań pasyjnych [w:] Jezus i Jego uczniowie w Markowym opisie męki. Kazania pasyjne, red. J. Twardy, Przemyśl 2006, s. 6-7 (Biblioteka Pomocy Kaznodziejskich, 16).

${ }^{41}$ Por. tamże, s. 11. 
całkowicie dobrowolnie. On, będąc doskonale sprawiedliwym i niewinnym, bezjakiejkolwiek wady, cierpiał za ludzi. Wziął na siebie nasze grzechy. Jego męka jest zbawcza - podjęta jako ofiara za odkupienie grzeszników.

Przez nieposłuszeństwo wobec woli Boga ludzie zasłużyli na śmierć i wieczne oddalenie od swojego Stwórcy. Jezus naprawił porządek zniekształcony przez ludzki grzech i obdarzył ludzkość jeszcze bardziej, dając ludziom możliwość udziału w naturze samego Boga. Jezus Chrystus okazał całkowite posłuszeństwo względem woli Bożej i przez to dokonał zbawienia ludzi; wysłużył wszystkim wieczne życie i szczęście.

Priorytetową kwestią, której nie można pominąć w kazaniach pasyjnych, jest miłość Boga do ludzi wyrażona na krzyżu. Męka Chrystusa - Jego krzyż - jest znakiem bezgranicznej miłości Boga do ludzi: „nikt nie ma większej miłości od tej, gdy ktoś życie swoje oddaje za przyjaciół swoich” (J 15, 13). To właśnie ta bezinteresowna, a zarazem bezgraniczna miłość Boga do ludzi jest ostatecznym i najgłębszym motywem krzyżowej ofiary Chrystusa ${ }^{42}$.

Kazanie pasyjne konfrontuje słuchaczy z dramatem pełnym kontrastów. Krzyż Chrystusa odsłania bowiem z jednej strony miłość Boga, z drugiej natomiast - grzech człowieka, podłość i nikczemność ludzi.

Zdaniem wybitnego znawcy kazań pasyjnych ks. prof. Jana Twardego w przybliżeniu znaczenia Chrystusowej męki pomocą służą obrazy biblijne, na przykład:

- obraz wykupu niewolnika, ponieważ ofiara Chrystusa ma charakter zastępczy;

- składanie winy Izraelitów na głowę kozła ofiarnego, który był wypędzony na pustynię (por. Kpł 16, 20-22);

- ofiary z pierwocin, które składano bogom z najlepszego zboża z całego pola i z najlepszego baranka z całej trzody - na krzyżu zaś został złożony w ofierze najdoskonalszy przedstawicieli rodzaju ludzkiego;

- kapłan i składanie przez niego ofiar - w przypadku Chrystusa On jest zarazem Kapłanem i Ofiarą złożoną na krzyżu.

Mówiąc o męce Pańskiej, należy pamiętać, że poszczególne jej epizody stanowią etapy jednego dzieła zbawienia. Nie wolno więc ich odrywać od siebie ani sztucznie dzielić. Należy preferować porządek chronologiczny. W przy-

42 Tamże, s. 13. 
padku zaś przyjęcia porządku tematycznego należy pamiętać o roku liturgicznym i narastającym dramacie paschalnym: kazania pasyjne rozpoczynają się w okresie pokutnym Wielkiego Postu, a kończą w okresie pasyjnym ${ }^{43}$.

Głoszenie słowa Bożego to nie tylko opowiadanie o wydarzeniach minionych. Istotnym elementem przepowiadania jest aktualizacja słowa Bożego. Należy zatem ukazywać znaczenie męki Chrystusa dla aktualnych słuchaczy żyjących w określonym środowisku parafialnym i w określonym czasie. W ścisłym związku z aktualizacją słowa Bożego pozostaje uniwersalizm, ponadczasowość krzyżowej ofiary Chrystusa. Ona rzuca wiele światła na codzienne ludzkie doświadczenie przeciwności, cierpienia, porażek, a nawet klęski. Krzyż jako forma życia chrześcijańskiego jest nieodłącznym elementem ludzkiej egzystencji ${ }^{44}$. Jezus z Nazaretu nie uwolnił ludzi od cierpienia, ale nadał każdemu ludzkiemu cierpieniu zbawczy sens. W tym tkwi dobra nowina. Podejmując temat cierpień Chrystusa, należy unikać sentymentalizmu. Zamiast niego o wiele cenniejsze jest wykazywanie zbawczego sensu męki Zbawiciela.

Tematyka kazań pasyjnych pomaga słuchaczom pogłębić motywację do zmiany sposobu życia, do rezygnacji z postawy konsumpcyjnej na rzecz życia wypełnionego ofiarą, zwłaszcza wyrażoną w czynach miłosierdzia wobec bliźnich.

W kazaniach pasyjnych jest również miejsce i czas na podjęcie zagadnień żywo dyskutowanych w społeczeństwie, pośród wiernych. Nie oznacza to, że głosiciel dostarczy rozwiązań ludzkich problemów, ale może na ludzkie problemy rzucić światło Chrystusowego krzyża; pomóc w spojrzeniu na wszystkie sprawy społeczne przez pryzmat nauczania Syna Bożego i Jego zbawczej ofiary. A to już bardzo wiele. Warto dodać, że gdy głoszone są aktualne kwestie społeczne, powinny one być podporządkowane głoszeniu tajemnicy krzyża i z nią związane. Takie ujęcie jest możliwe. Nie do polecenia jest natomiast - skądinąd bardzo ważne - prezentowanie nauczania społecznego niezależnie od ewangelicznych opowiadań o męce Pańskiej ${ }^{45}$.

43 Tamże, s. 14-18.

44 Por. tamże, s. 18-23.

45 Przykładem nie do naśladowania są kazania na temat społecznej nauki Kościoła ks. prymasa Józefa Glempa pt. Boskie i cesarskie. Ewangelia wobec polityki. Kazania pasyjne w kościele św. Krzyża w Warszawie Anno Domini 1995, Warszawa 1995. 
Ponadto tym, czego należy unikać, jest zbyt uproszczone obwinianie poszczególnych osób za śmierć Chrystusa. Szczególnie trzeba pamiętać o tym, że nie wolno obarczać winą za tę śmierć ani wszystkich Żydów żyjących w czasach Pana Jezusa, bo przecież byli wśród nich i ludzie sprawiedliwi, jak na przykład Maryja, Matka Jezusa, ani tym bardziej Żydów żyjących dzisiaj ${ }^{46}$. Za mękę i śmierć Chrystusa ponoszą winę grzeszni ludzie wszystkich czasów i narodów. Chrystus umarł za wszystkich ${ }^{47}$.

Wypowiadając się na temat treści kazań pasyjnych, ks. prof. Edward Staniek przypomina, że „autorzy Ewangelii najwięcej miejsca poświęcili dokładnym opisom wydarzeń Wielkiego Tygodnia. Tymczasem rok liturgiczny nie przewiduje - poza Pasją w Niedzielę Palmową oraz w Wielki Piątek - ani czytania, ani tym bardziej wyjaśniania tych rozdziałów Ewangelii. Kazania pasyjne należy traktować jako komentarz do ewangelicznych opisów Wielkiego Czwartku, Wielkiego Piątku i Wielkiej Niedzieli”48. Zdaniem autora tych słów na tematykę dobrego kazania pasyjnego składa się męka Chrystusa, którą należy łączyć z Jego zmartwychwstaniem. Ponadto należy mówić o tajemnicy miłości Boga i tajemnicy grzechu, o tajemnicy cierpienia i o tajemnicy śmierci, a także problemów nurtujących słuchaczy w perspektywie zmagania dobra ze złem ${ }^{49}$.

\subsection{Przykładowe serie tematyczne}

Zdaniem ks. prof. Edwarda Stańka „kazania pasyjne należą do najtrudniejszych [...]. Tajemnica trudności tych kazań polega między innymi na tym, że posiadają one charakter cykliczny. Kaznodzieja musi zaplanować sześć kazań na jeden temat. Ważnym elementem konstrukcyjnym jest to, by prowadzić stopniowo słuchaczy - niedziela po niedzieli - na coraz wyższy stopień przeżycia"50.

46 II Sobór Watykański, Deklaracja o stosunku Kościoła do religii niechrześcijańskich Nostra aetate, 4; zob. W. Przyczyna, O Żydach z ambony, „Homo Dei” 61 (1992), nr 4, s. 112-119; J. Twardy, Wskazania i przestrogi dla głosicieli kazań pasyjnych, [w:] Męka Jezusa szkoła człowieczeństwa. Kazania pasyjne, red. J. Twardy, Przemyśl 2007, s. 13 (Biblioteka Pomocy Kaznodziejskich, 17).

${ }_{47}$ Por. Katechizm Kościoła katolickiego, 597-598.

48 E. Staniek, Z kaznodziejskiego warsztatu, dz. cyt., s. 106.

${ }^{49}$ Por. tamże.

50 Tamże, s. 107. 
O tematyce serii kazań decyduje sam głosiciel. Dla przykładu w zbiorowym opracowaniu zatytułowanym Przez krzyż do chwały ${ }^{51}$ zostały zaproponowane następujące tematyczne serie kazań pasyjnych:

- Droga krzyżowa Maryi: 1. Żłóbek zapowiedzią krzyża; 2. Jezus znakiem sprzeciwu; 3. Duszę Maryi przeniknie miecz: 4. „Z bólem serca szukaliśmy Ciebie” (Łk 2, 48); 5. Stała Matka Boleściwa; 6. „Oto Matka twoja" (J 19, 27).

- Myślenie z wnętrza cierpienia: 1. Dwie kultury; 2. Szansa człowieka; 3. Klamra prawa; 4. Ból lęku; 5. Bóg Ewangelii.

- Pasja według św. Marka: 1. Spisek i zdrada Judasza; 2. Eucharystia - testament życia i śmierci Jezusa; 3. Zadatek nowej uczty w królestwie Bożym; 4. Modlitwa Jezusa w ogrodzie Getsemani - dopełnienie daru życia; 5. Upadek - żal - powstanie - wytrwanie; 6. Droga krzyżowa i śmierć skazanego; 7. Pogrzeb Jezusa i nasz - Jego i nasz grób.

- Ostatniesłowa Jezusa: 1. Chrystus prosi o łaskę przebaczenia;2. Chrystus nie usunął krzyża, lecz zawisnął na nim; 3. Chrystus umiera za wolność człowieka; 4. Z Jezusem możemy przeżyć własną śmierć; 5. Chrystus - człowiek, który czyni dar z siebie.

Kazania pasyjne pogłębione biblijnie można opracować, wykorzystując wewnętrznąjedność Starego i Nowego Testamentu. Tematem może być: Zapowiedź zbawieniai jego realizacja w Chrystusie. Poszczególne kazania tej serii mogą podejmować następujące zapowiedzi osoby i dzieła Chrystusa: 1 . Adam - Chrystus; 2. Ofiara Abrahama i Izaaka - Ofiara Chrystusa na krzyżu i w Eucharystii; 3. Mojżesz: wyzwolenie z Egiptu i nadanie Prawa - Chrystus: Kazanie na górze i wyzwolenie z niewoli szatana; 4. Cierpiący Sługa Jahwe - umęczony Mesjasz; 5. Baranek paschalny - Baranek Boży; 6. Wąż na pustyni - wywyższony Chrystus (na podstawie Ewangelii według św. Jana).

Tematem zawsze bliskim ludziom, a zarazem znakomicie nadającym się do podjęcia w kazaniach pasyjnych, jest doświadczenie cierpienia. Temat może nosić tytuł: Cierpienie człowieka w świetle orędzia i krzyża Chrystusa. Poszczególne kazania mogą podejmować następujące zagadnienia: 1. Dawid - cierpienie za grzechy; 2. Hiob - cierpienie niezawinione; 3. Cierpiący Sługa Jahwe - cierpienie ekspiacyjne; 4. Wierność braci

51 Przez krzyż do chwały: medytacje, kazania, nabożeństwa pasyjne, red. J. Nowak, Kielce 2000. 
machabejskich - autentyczna i konsekwentna religijność, męczeństwo za wiarę, wierność sumieniu; 5. Jeremiasz - cierpienie za głoszenie prawdy; 6. Maryja - mistyczne współcierpienie.

Godny uwagi jest sam symbol krzyża. Trzeba jednak uważać, by przy takiej serii nie odejść od przepowiadania osobowego skoncentrowanego na osobie i wydarzeniach z życia Jezusa Chrystusa. Temat serii może być zapożyczony z tytułu pieśni pasyjnej: Krzyżu święty nade wszystko albo Zbawienie przyszło przez krzyż. Poszczególne kazania mogą dotyczyć następujących aspektów: 1. Krzyż w życiu chrześcijanina; 2. Symbolika znaku krzyża; 3. Krzyż i misterium miłości; 4. Miejsce krzyża w życiu publicznym; 5. Krzyż znakiem przebaczenia; 6. Krzyż znakiem zbawienia. Jako pomoc do opracowania kazań pasyjnych skoncentrowanych na podstawowym symbolu chrześcijan, jakim jest krzyż, mogą posłużyć medytacje autorstwa znakomitego polskiego biblisty prof. Józefa Kudasiewicza zatytułowane Zbawienie przyszło przez krzyż ${ }^{52}$. Zostały w nich podjęte takie kwestie, jak: 1. Znak krzyża; 2. Zgorszenie krzyżem; 3. Próba wyjaśnienia tajemnicy krzyża; 4. Krzyż w życiu chrześcijanina; 5. Głoszenie krzyża dzisiaj.

\section{Struktura kazań pasyjnych}

Kazanie pasyjne różni się od homilii. W przypadku homilii podczas mszy świętej jej głosiciel otrzymuje teksty wyznaczone w lekcjonarzu odpowiednio do celebracji. W przypadku kazania pasyjnego to sam głosiciel dobiera odpowiednie teksty biblijne. Cieszy się w tym względzie dużą autonomią.

Kazanie pasyjne posiada strukturę kazania klasycznego. Rozpoczyna się od pozdrowienia i wstępu. Po nim następuje zasadnicza część kazania, a po niej zakończenie. Przedstawmy dla przykładu strukturę kazania pasyjnego, dla którego zasadniczym źródłem jest perykopa z Ewangelii św. Jana o podziale szat Chrystusa:

Żołnierze zaś, gdy ukrzyżowali Jezusa, wzięli Jego szaty i podzielili na cztery części, dla każdego żołnierza po części; wzięli także tunikę. Tunika zaś nie była szy-

52 J. Kudasiewicz, Zbawienie przyszło przez krzyż, [w:] Przez krzyż do chwaty..., dz. cyt., s. 130143; zob. tenże, Spotkanie z Jezusem w tajemnicy paschalnej. Medytacje biblijno-liturgiczne, Kielce 2003. 


\section{ks. Henryk Sławiński}

ta, ale cała tkana od góry do dołu. Mówili więc między sobą: Nie rozdzierajmy jej, ale rzućmy o nią losy, do kogo ma należeć. Tak miały się wypełnić słowa Pisma: Podzielili między siebie szaty, a los rzucili o moją suknię. To właśnie uczynili żołnierze (J 19, 23-24).

1. Pozdrowienie, wstęp - nawiązanie do męki Pańskiej;

1.1. przedstawienie sceny;

1.2. wyjaśnienie fragmentu opisu męki Pańskiej oraz symboliki szat i tuniki;

2. rozwinięcie;

2.1. historyczny obraz podziałów Kościoła;

2.2. przyczyna podziałów;

2.3. nasz udział w dzieleniu szaty Chrystusa;

2.4. Jezusowa modlitwa o jedność Kościoła $(\mathrm{J} 17,11)$;

2.5. nasz wkład w budowanie jedności Kościoła - pozytywny przykład;

3. zakończenie, którego częścią może być zaproszenie do udziału w kolejnym nabożeństwie.

We wstępie do pierwszego kazania pasyjnego warto zapowiedzieć tematykę całej serii. W pozostałych można wspomnieć temat poprzedniego i zapowiedzieć temat głoszonego kazania. Częścią zakończenia może być modlitwa do Jezusa ukrzyżowanego, zwłaszcza że po kazaniu następuje adoracja Najświętszego Sakramentu, a po błogosławieństwie adoracja krzyża. Nie ma jednej, ściśle określonej struktury kazania pasyjnego. Warto jednak dbać o klarowność, jednotematyczność i o porządek przekazu myśli. Sprzyja on zapamiętaniu kazania.

Mówiąc o formalnych aspektach kazania pasyjnego, warto jeszcze uwzględnić niezwykle cenną uwagę ks. Edwarda Stańka o tym, że „ludzie, słuchając kazania, spoglądają na monstrancję. Kaznodzieja nie może przesłonić sobą i swoim rozważaniem Chrystusa. Świadomość Jego obecności w Najświętszym Sakramencie decyduje o stylu, formie oraz pokornej postawie kaznodziei" ${ }^{53}$.

53 E. Staniek, Z kaznodziejskiego warsztatu, dz. cyt., s. 107. 


\section{Zakończenie}

Prawda o Jezusie Chrystusie, ukrzyżowanym i zmartwychwstałym Synu Bożym, stanowi centrum chrześcijańskiego przepowiadania. Głosiciele słowa Bożego głoszą ją, odczytując wciąż na nowo jej sens dla zmieniających się słuchaczy. Istnieją przy tym szczególne okoliczności, w czasie których głoszony jest przede wszystkim Chrystus ukrzyżowany. Okazjami, które szczególnie służą takiemu przepowiadaniu, są Niedziela Palmowa i Wielki Piątek oraz nabożeństwa pasyjne, a przede wszystkim nabożeństwo gorzkich żali. Nabożeństwa pasyjne i głoszone podczas nich kazania pasyjne nie są fenomenem katolickim. Kaznodzieje różnych wyznań chrześcijańskich pielęgnują tradycję kazań pasyjnych.

Poza Polską kazania pasyjne głoszone są w postaci konferencji albo kazań w okresie wielkiego postu. Kazania pasyjne służące rozważaniu męki Pańskiej głoszone są w kościołach katolickich w okresie Wielkiego Postu. Na przykład w katedrze Notre Dame w Paryżu przybierają one postać konferencji, w których podejmowane są aktualne zagadnienia dotyczące wiary i życia wyznawców Chrystusa. Dla przykładu, w 2013 roku, obchodzonym z woli papieża Benedykta XVI jako Rok Wiary, seria kazań Conférences de Carême 2013 à Notre-Dame de Paris została zatytułowana: Wierzyć, szansa dla wszystkich. Głosicielami konferencji byli, obok arcybiskupa Paryża, kardynała André Vingt-Trois, jego biskupi sufragani ${ }^{54}$. W Niemczech z kolei kazania pasyjne, tzw. Fastenpredigten, głoszone są w różnym kontekście. Na przykład w katedrze w Fuldzie w 2013 roku wygłaszał je oficjał prof. dr Lothar Wächter podczas uroczystych niedzielnych mszy świętych o $9.30^{55}$.W katedrze w Osnabrück kazania pasyjne wygłaszane były przez różnych duchownych podczas nabożeństwa w niedzielne popołudnie ${ }^{56}$, natomiast w katedrze

54 Conférences de carême 2013 à Notre-Dame de Paris : Croire, une chance pour tous", www. paris.catholique.fr/-Conferences-de-Careme-2013-a-Notre-.html (9.12.2013).

55 Sechs Fastenpredigten im Osnabrücker Dom, www.bistum-fulda.de/bistum_fulda/presse_ medien/liste_pressemeldungen/2013/2013_01/bpd_2013_2/bpd_20130214_02_Fastenpredigten_ im_Dom.php (9.12.2013).

${ }_{56}$ Fastenpredigten im Dom, www.bistum-osnabrueck.de/service/presse/detailansicht/artikel/sechs-fastenpredigten-im-osnabruecker-dom.html (9.12.2013). 
w Paderborn - w środy po wieczornych mszach świętych przez przedstawicieli środowiska akademickiego, nie wyłączając kobiet ${ }^{57}$.

Gdy chodzi o tematykę kazań pasyjnych, szczególnie w ostatnim czasie, po II Soborze Watykańskim, dzięki inspirowanej nim teologii biblijnej i homiletyce podkreśla się w przepowiadaniu pasyjnym najpierw zbawcze orędzie i owoce męki Pańskiej, a potem dopiero zobowiązania moralne wynikające z tego wydarzenia zbawczego. Postępowanie uczniów Chrystusa jest odpowiedzią na Jego zaproszenie do zjednoczenia z Nim w Jego cierpieniach, do zaparcia się samego siebie i naśladowania Syna Człowieczego w codziennym życiu. Kazania pasyjne mają też ożywiać u słuchaczy praktyczną troskę o Chrystusa cierpiącego w drugim człowieku.

57 Fastenpredigten im Hohen Dom..., www.erzbistum-paderborn.de/38-Nachrichten/15056,Fastenpredigten-im-Hohen-Dom-befassen-sich-mit-geistlichen-Impulsen-aus-der-Botschaft-des-Zweiten-Vatikanischen-Konzils.html (9.12.2013). 


\section{Summary}

\section{The Origin, Context and Topics of Sermons on the Passion of Jesus Christ}

The proclamation about the crucified and risen Jesus Christ is the nucleus of the Christian preaching. There are however moments in the liturgical year in which the Passion of Jesus is emphasized in a special way. In addition to the liturgy of Palm Sunday and Good Friday there is also popular devotion during the Lent time, which delivers opportunity to preach the Passion of Jesus crucified. The most famous popular Passion piety associated with the proclamation of the word of God are: The last words of Christ from the Cross and a special devotion in Poland called "Gorzkie żale" - "Bitter complains". The latter is typically Polish. An important part of this devotion is the sermon, whose main theme is the salvific dimension of the Passion of Christ. It is evangelical story about the crucifixion of Jesus Christ, which provides for the source for these sermons. This article presents the origins, context, content and the structure of sermons preached in Poland during the popular passion devotion.

Keywords: preaching, passion of Jesus Christ, Lent, seven last words of Jesus

\section{Geneza, kontekst i tematyka kazań pasyjnych}

Głoszenie prawdy o Chrystusie ukrzyżowanym i zmartwychwstałym stanowi jądro chrześcijańskiego przepowiadania. Są jednak w ciągu roku kościelnego okoliczności, w których dominuje tematyka pasyjna. Oprócz liturgii Niedzieli Palmowej i Wielkiego Piątku okazją do przepowiadania pasyjnego są nabożeństwa ludowe służące rozważaniu męki Pańskiej, odprawiane głównie w okresie Wielkiego Postu. Są one wyrazem pobożności pasyjnej. Do najbardziej znanych nabożeństw pasyjnych związanych z głoszeniem słowa Bożego należą: nabożeństwo ostatnich słów Chrystusa z krzyża i nabożeństwo gorzkich żali. To ostatnie jest typowo polskie. Jego istotnym elementem jest kazanie pasyjne, którego podstawowym tematem jest zbawczy wymiar męki Chrystusa.Źródłem dla tych kazań są ewangeliczne opowiadania o ukrzyżowaniu Chrystusa. Artykuł przedstawia genezę, kontekst, tematykę i strukturę kazań pasyjnych.

Słowa kluczowe: przepowiadanie, męka Jezusa Chrystusa, Wielki Post, siedem ostatnich słów Jezusa

\section{Bibliografia}

Dizionario di omiletica, ed. M. Sodi, A. M. Triacca, Torino-Bergamo 1998.

Bańbuła M., Bartkowski B., Gorzkie Żale, [w:] Encyklopedia katolicka, t. 5, red. L. Bieńkowski, Lublin 1989, k. 1309-1311. 


\section{ks. Henryk Sławiński}

Cantalamessa R., La vita nella Signoria di Cristo, Milano $1989^{4}$.

Chorzępa M., Gorzkie żale, ich geneza i rozwój historyczny, „Nasza Przeszłość” 12 (1969), s. $221-258$

Conférences de carême 2013 à Notre-Dame de Paris: Croire, une chance pour tous, www. paris.catholique.fr/-Conferences-de-Careme-2013-a-Notre-.html (9.12.2013).

Fastenpredigten im Dom, www.bistum-osnabrueck.de/service/presse/detailansicht/ artikel/sechs-fastenpredigten-im-osnabruecker-dom.html (9.12.2013).

Fastenpredigten im Hohen Dom..., www.erzbistum-paderborn.de/38-Nachrichten/15056,Fastenpredigten-im-Hohen-Dom-befassen-sich-mit-geistlichen-Impulsen-aus-der-Botschaft-des-Zweiten-Vatikanischen-Konzils.html (9.12.2013).

Glemp J., Boskie i cesarskie. Ewangelia wobec polityki. Kazania pasyjne w kościeleśw. Krzyża w Warszawie Anno Domini 1995, Warszawa 1995.

Gnilka J., Das Matthäusevangelium, Bd. I, Freiburg-Basel-Wien 1986.

Harries R., Wstẹp, [w:] Siedem ostatnich słów z krzyża. Odczytywane dzisiaj, red. E. Nevell, przekł. A. Nowak, Kraków 2004.

Itinerarium Aetheriae; Sources Chrétiennes, 21; Corpus Christianorum. Series Latina 175, 37-103.

Jan Paweł II, Katechizm Kościoła katolickiego (11.10.1992), Poznań 1994.

Jan Paweł II, Przekroczyć próg nadziei.Jan Paweł II odpowiada na pytania Vittoria Messoriego, Lublin 1994.

Kudasiewicz J., Spotkanie z Jezusem w tajemnicy paschalnej. Medytacje biblijno-liturgiczne, Kielce 2003.

Kudasiewicz J., Zbawienie przyszło przez krzyż, [w:] Przez krzyż do chwały: medytacje, kazania, nabożeństwa pasyjne, red. J. Nowak, Kielce 2000, s. 130-143.

Leksykon liturgii, oprac. B. Nadolski, Poznań 2006.

Leon Wielki, Sermo 52,5; Patrologia Latina, 54316.

Liber comitis; Patrologia Latina, 30, 502-503.

Maggioni C., Via Pacis - Via Crucis - Via Matris - Via Lucis, [w:] Dizionario di omiletica, ed. M. Sodi, A. M. Triacca, Torino-Bergamo 1998, s. 1651-1654.

Messia A., The devotion of the three hours' agony on Good Friday, London 1899.

Pałęcki W., Pasja. W liturgii, [w:] Encyklopedia katolicka, t. 14, red. E. Gigilewicz, Lublin 2010, k. 1432-1433.

Pałubska Z., Leonard z Porto Maurizio, [w:] Encyklopedia katolicka, t. 10, red. A. Bednarek, Lublin 2004, k. 789-790.

Peregrinatio Aetheriae, [w:] Gingras, G. E., New Catholic encyclopedia, 2003, www.encyclopedia.com/article-1G2-3407703567/egeria-itinerarium.html (9.12.2013).

Popławski J. M., Droga krzyżowa, [w:] Leksykon duchowości katolickiej, red. M. Chmielewski, Lublin-Kraków 2002, s. 222-223;

Popławski J. M., Duchowośćpasyjna, [w:] Leksykon duchowości katolickiej, red. M. Chmielewski, Lublin-Kraków 2002, s. 637-638.

Popławski J. M., Kaspra Drużbickiego teologia krzyża, Lublin 1997.

Przez krzyż do chwały: medytacje, kazania, nabożeństwa pasyjne, red. J. Nowak, Kielce 2000. 
Sechs Fastenpredigten im Osnabrücker Dom, www.bistum-fulda.de/bistum_fulda/presse_ medien/liste_pressemeldungen/2013/2013_01/bpd_2013_2/bpd_20130214_02_Fastenp redigten_im_Dom.php (9.12.2013).

Sinka T., Gorzkie Żale: geneza, teologia, przyszłość, „Ruch Biblijny i Liturgiczny” 54 (2001) nr 1, s. 51-55.

Sławiński H., Ambiwalentne postawy człowieka wobec cierpienia, „Studia Włocławskie” 10 (2007), s. 213-220.

Sławiński H., Jak dzisiaj głosić Chrystusa ukrzyżowanego?, „Ateneum Kapłańskie” 541 (1999), s. 383-396.

Sławiński H., Naśladowanie Chrystusa ukrzyżowanego według synoptyków, „Studia Włocławskie" 2 (1999), s. 253-265.

Sławiński H., Przepowiadanie Chrystusowego krzyża, Warszawa 1997.

Sobór Watykański II, Deklaracja o stosunku Kościoła do religii niechrześcijańskich Nostra aetate.

Przyczyna W., O Żydach z ambony, „Homo Dei” 61 (1992), nr 4, s. 112-119.

Staniek E., Z kaznodziejskiego warsztatu, Kraków 1997, s. 106-107.

Szymoniak W., Gorzkie Żale, „Materiały Homiletyczne” 40 (1981), s. 4-7.

Św. Augustyn, Sermones de tempore 232; Patrologia Latina, 38, 1108.

Twardy J., Głoszenie kazań o świadkach męki Chrystusa, [w:] Świadkowie męki Chrystusa, red. J. Twardy, Przemyśl 2004, s. 5-18.

Twardy J., Kazania na temat zapowiedzi Męki Pańskiej, [w:] Syn Człowieczy musi wiele cierpieć? Kazania pasyjne, red. J. Twardy, Przemyśl 1997, s. 4-5 (Biblioteka Pomocy Kaznodziejskich, 7).

Twardy J., Kazania pasyjne o siedmiu boleściach Maryi, [w:] Matka Bolesna. Kazania pasyjne, red. J. Twardy, Przemyśl 2003, s. 5-9 (Biblioteka Pomocy Kaznodziejskich, 13).

Twardy J., Treść kazań pasyjnych, [w:] Jezus i Jego uczniowie w Markowym opisie męki. Kazania pasyjne, red. J. Twardy, Przemyśl 2006, s. 5-30 (Biblioteka Pomocy Kaznodziejskich, 16).

Twardy J., Wskazania i przestrogi dla głosicieli kazań pasyjnych, [w:] Męka Jezusa szkoła człowieczeństwa. Kazania pasyjne, red.J. Twardy, Przemyśl 2007, s. 5-19 (Biblioteka Pomocy Kaznodziejskich, 17).

Zamelek M., Tematyka współczesnych kazań pasyjnych - na podstawie tekstów publikowanych w periodykach homiletycznych ,Biblioteka Kaznodziejska”, „Materiały Homiletyczne” $i$ „Wspótczesna Ambona” w latach 1980-2005, praca magisterska, mps, Wydział Teologiczny Uniwersytetu Adama Mickiewicza, Poznań 2011. 